\title{
Acute Renal Failure: A Complication of Datura Poisoning
}

\section{Dubey $\mathrm{PK}^{1^{*}}$ and Sanjeev OP ${ }^{2}$}

${ }^{1}$ Department of Anesthesiology, Indira Gandhi Institute of Medical Sciences, Patna, India

${ }^{2}$ Department of Anesthesiology and Critical Care Medicine, Dr. Ram Manohar Lohiya Institute of Medical Sciences, Lucknow, India

"Corresponding author: Prakash K Dubey, Professor, Department of Anesthesiology, Indira Gandhi Institute of Medical Sciences, IGIMS Campus, Patna, India, Tel: + 919430511851; E-mail: pkdubey@hotmail.com

Received date: June 29, 2017; Accepted date: July 19, 2017; Published date: July 20, 2017

Copyright: (C) 2017 Dubey PK, et al. This is an open-access article distributed under the terms of the Creative Commons Attribution License, which permits unrestricted use, distribution, and reproduction in any medium, provided the original author and source are credited.

\section{Abstract}

Datura stramonium is a poisonous plant found in many parts of the world. Presented here is a case of datura root poisoning that was followed by acute renal failure in a 28 year old man.

The patient was administered datura root paste as a treatment for hemorrhoids. After 48 hrs, he started showing symptoms of poisoning and later on presented with acute renal failure. He was given supportive treatment and hemodialysis was performed. The patient made a satisfactory recovery thereafter.

Ingestion of Datura stramonium root is uncommon and renal failure in association with datura poisoning in humans is rare. We suspect datura root ingestion as the cause of renal failure and recommend monitoring of renal function in such cases.

Keywords: Renal failure; Intoxication; Datura root; Hemodialysis

\section{Key Message}

Ingestion of Datura stramonium root is uncommon and renal failure has not been described in association with datura poisoning in humans. We suspect datura root ingestion as the cause of renal failure and recommend monitoring of renal function in such cases.

\section{Introduction}

Datura stramonium, also known as thorn apple, mad apple, devil's apple, apple of Peru, angel's trumpet, devil's trumpet, stinkweed, Jamestown or Jimson weeds, moon flower, witch's thimble, green dragon or tolguacha is a poisonous plant found in many parts of the world [1]. All parts of the plant are poisonous and are ingested, smoked or absorbed topically for recreation. Ingestion of datura root, however, is unheard of and so is subsequent renal failure. There have been, however, reports of elevated creatinine kinase with or without rhabdomyolysis [2-4].

In India leaves, flowers and fruits of this plant are offered to Lord Shiva and many medicinal uses of this plant have been described in Ayurveda. We report a case of datura root poisoning that led to acute renal failure in a 28 year old man.

\section{Case history}

A 28 year-old man of $56 \mathrm{~kg}$ body weight was suffering from per rectal bleeding for the last 1 year which was diagnosed as hemorrhoids. He sought help of a village practitioner and was advised datura root paste PO. He started taking 2 Tsf (Tons per Square Foot) of this paste daily morning. On the third morning he vomited just after taking the paste and became restless and disoriented. Following this he was treated by a local physician where he received intravenous pantoprazole, mannitol 20\% $300 \mathrm{ml}$ and 2 litres of Ringer's lactate each day for 2 days. On day 3 , his urinary bladder was catheterized as he had not passed urine for 24 hours. Around $800 \mathrm{ml}$ of urine was drained. Laboratory investigations showed hemoglobin $5.5 \mathrm{gram} / \mathrm{dl}$, blood urea $56 \mathrm{mg} / \mathrm{dl}$ and serum creatinine $2.8 \mathrm{mg} / \mathrm{dl}$. On fourth day his blood urea and serum creatinine rose to $76 \mathrm{mg} / \mathrm{dl}$ and $3.6 \mathrm{mg} / \mathrm{dl}$ respectively. He was referred to our center for the management of worsening renal function and altered neurological status. At the time of admission he was febrile (38), restless, delirient and disoriented with a Glasgow Coma Scale score of 12 . He was talkative but irrelevant and illogical. His tongue was dry; pupil was dilated with sluggish reaction to light. Pulse rate was $90 \mathrm{BPM}$ (Beats per minute) and blood pressure was $140 / 86 \mathrm{~mm}$ of $\mathrm{Hg}$. On the basis of history and clinical features datura poisoning was suspected. Intravenous infusion of midazolam was used to control his agitation. Urine output was $150 \mathrm{ml}$ in 8 hours. His blood urea was $116 \mathrm{mg} / \mathrm{dl}$ and serum creatinine was $11 \mathrm{mg} / \mathrm{dl}$. Hemodialysis was done on two consecutive days and thereafter alternate day for two days. His blood urea came down to $40 \mathrm{mg} / \mathrm{dl}$. During this period he was transfused 3 units of packed red blood cells. On regaining consciousness, he confirmed datura root ingestion.

Twelve days after he started ingesting datura root paste, and after remaining admitted for eight days, the patient was discharged from the hospital.

\section{Discussion}

Datura stramonium is an annual plant and contains a variety of tropine alkaloids hyoscyamine, scopolamine, and atropine [5]. One hundred of datura seeds contain upto $6 \mathrm{mg}$ of atropine and other plant parts contain varying amount of alkaloids.The amount of these alkaloids depends on datura species, cultivation factors like temperature and moisture and storage conditions. Interestingly, toxicity is not uniform and predictable but varies from leaf to leaf, plant to plant and season to season. This makes the ingestion extremely 
dangerous as the total dose cannot be calculated with certainty. Toxicity results from ingestion that may be accidental or for recreational purpose [6].

Symptoms of Datura stramonium toxicity have been described as an extension of the therapeutic effects of the alkaloids it contains. With a dosage equivalent to $0.5 \mathrm{mg}$ atropine, dryness of the mouth appears first and coma, cardiac and respiratory arrest are seen in the advanced phase of over dosage (Table 1).

\begin{tabular}{|l|l|}
\hline $\begin{array}{l}\text { Dose in atropine } \\
\text { equivalent }\end{array}$ & Clinical effect \\
\hline $0.5 \mathrm{mg}$ & Dryness of the mouth, decreased sweating. \\
\hline $1.0 \mathrm{mg}$ & $\begin{array}{l}\text { Pupillary dilatation, loss of accommodation and } \\
\text { tachycardia. }\end{array}$ \\
\hline $3-5 \mathrm{mg}$ & $\begin{array}{l}\text { Intoxication, visual disturbance, flushing, palpitation and } \\
\text { tachycardia. }\end{array}$ \\
\hline$>5 \mathrm{mg}$ & $\begin{array}{l}\text { Inhibition of micturition and gastrointestinal peristalsis, } \\
\text { confusion, agitation, delirium and fever. }\end{array}$ \\
\hline$>10 \mathrm{mg}$ & $\begin{array}{l}\text { Hallucination, convulsion, coma, cardiac and respiratory } \\
\text { arrest. }\end{array}$ \\
\hline
\end{tabular}

Table 1: Stramonium toxicity: the approximate dose effect relationship in atropine equivalence [7].

An estimated lethal dose in an adult is more than $10 \mathrm{mg}$ atropine or more than 2-4 mg scopolamine. Coma with focal neurological signs and decorticate posture after datura poisoning has been attributed to the atropine effect, the central anticholinergic syndrome [5]. Poisoning with datura leads to acute urinary retention that was also seen in our patient. Based on the patient's symptomology, we can presume that the patient had consumed more than $5 \mathrm{mg}$ atropine equivalent of datura root. Differential diagnosis in datura poisoning includes other hallucinogenic intoxication.

Accidental datura root poisoning has been reported in an 84 years old male who ate a nickel-sized bite mistaking it for horseradish [7]. Typical poisoning symptoms appeared within an hour and disappeared within two days. In spite of taking a larger dose, the symptoms started after $48 \mathrm{hrs}$ and persisted for more than a week in our patient. We are unable to explain this pattern and it may be attributed to the age difference between the patients, individual response of the patient or the toxicity potential of the ingested root of stramonium. The time course of poisoning can be shortened by using physostigmine that can also be lifesaving when symptoms are severe. Our patient reported after four days of poisoning and the symptoms were mild enough to warrant any antidote.

Facilities for laboratory diagnosis of datura poisoning are not available at our institution. However, it is known that the diagnosis is mainly clinical and toxicity may be produced without detectable levels of hyoscyamine, scopolamine and atropine in blood [6]. In this patient, a definite history of datura root ingestion was available.

Administration of aqueous seed extract and ethanol extract of leaves of Datura stramonium in rats has been reported to be nephrotoxic [8]. Accidental poisoning of horses with Datura stramonium had shown toxic liver dystrophy, dystrophic and necrotic changes in the renal parenchyma and myocardium on necropsy [9]. Datura stramonium has caused nephrotoxicity in domestic animals [10].

Renal failure has not been described in association with datura root poisoning in humans. Rhabdomyolysis with elevated serum creatinine kinase has been reported which has a benign course of illness without renal impairment. It has been suggested to obtain a baseline serum creatine kinase concentration to identify patients with higher risk for rhabdomyolysis and renal impairment [2]. We suspect that datura root poisoning led to renal failure in this patient. However, contribution of poor fluid intake in hot weather cannot be excluded as the exact details of fluid intake after ingestion of the datura root paste and before hospitalization was not available. We recommend monitoring of renal function in patients of datura root poisoning especially when symptoms persist for longer than usual.

\section{References}

1. Hung OL, Lewin NA, Howland MA (2002) Herbal preparations. Goldfrank's toxicologic emergencies, McGraw-Hill, New York 7: 1129-1149.

2. Blackford MG, Fitzgibbon JJ, Reed MD (2010) Assessment of serum creatinine kinase among adolescent patients following jimsonweed (Datura stramonium) and moonflower (Datura inoxia) ingestions: A review of 11 cases. Clin Toxicol (Phila) 48: 431-434.

3. Ertekin V, Selimodlu MA, Altinkaynak S (2005) Combination of unusual presentations of Datura stramonium in a child: Rhabdomyolysis and fulminant hepatitis. J Emerg Med 28: 227-230.

4. DeFrates L, Hoehns J, Sakornbut E, Glascock D, Tew A (2005) Antimuscaranic intoxication resulting from ingestion of moonflower seeds. Ann Pharmacother 39: 173-176.

5. Oberndorfer S, Grisold W, Hinterholzer G, Rosner M (2002) Coma with focal neurological signs caused by Datura stramonium intoxication in a young man. J Neurol Neurosurg Psychiatry 73: 458-459.

6. Palmer M, Betz JM (2002) Plants. Goldfrank's toxicologic emergencies, McGraw-Hill, New York 7: 1150-1182.

7. Hanna JP, Schmidley JW, Braselton WE (1992) Datura delirium. Clin Neuropharmacol 15: 109-113.

8. Gidado A, Zainab AA, Hadiza MU, Serah DP, Anas HY, et al. (2007) Toxicity studies of ethanol extract of the leaves of Datura stramonium in rats. African J Biotech 6: 1012-1015.

9. Binev R, Valchev I, Nikolov J (2006) Clinical and pathological studies of Jimson weed (Datura stramonium) poisoning in horses. Trakia J Sci 4 : 56-63.

10. Oladosu LA, Case AA (1979) Large animal hepatotoxic and nephrotoxic plants. Vet Hum Toxicol 21: 363-365. 